The Press and the Consolidation of Democracy in Turkey

Author(s): Metin Heper and Tanel Demirel

Source: Middle Eastern Studies, Vol. 32, No. 2 (Apr., 1996), pp. 109-123

Published by: Taylor \& Francis, Ltd.

Stable URL: https://www.jstor.org/stable/4283795

Accessed: 31-01-2019 16:32 UTC

JSTOR is a not-for-profit service that helps scholars, researchers, and students discover, use, and build upon a wide range of content in a trusted digital archive. We use information technology and tools to increase productivity and facilitate new forms of scholarship. For more information about JSTOR, please contact support@jstor.org.

Your use of the JSTOR archive indicates your acceptance of the Terms \& Conditions of Use, available at https://about.jstor.org/terms

Taylor \& Francis, $L t d$. is collaborating with JSTOR to digitize, preserve and extend access to Middle Eastern Studies 


\title{
The Press and the Consolidation of Democracy in Turkey
}

\author{
METIN HEPER and TANEL DEMIREL
}

From the second half of the nineteenth century onwards the press played a critical role in Turkish politics. In fact, in Turkey the press came to play too prominent a role in politics and this undermined the consolidation of democracy in that country.

The first generation of journalists in Turkey emerged in the 1860s from among the ranks of the bureaucratic intelligentsia who were trying to put an end to the absolute rule of the Ottoman sultan. The members of the intelligentsia were preoccupied with the salvation of the empire; in their estimation the solution lay in making public decision-making more rational. This could be achieved only if the sultan and the small coterie of higher bureaucrats around him did not monopolize the decision-making process. According to Namık Kemal, the leading thinker, novelist and journalist of the time, and his professional colleagues, progress depended on free institutions, and free institutions were maintained by an enlightened public opinion; one of the chief media in this process was the press.'

Namık Kemal thought that public opinion should reflect public morality 'an aggregate of feelings for freedom, justice, and one's country'. ${ }^{2}$ The said public morality derived from the novel idea of patriotism - loyalty to one's fatherland, and not to the sultan and his ministers or to the Islamic community and its authorized interpreters - that Namık Kemal fervently espoused. ${ }^{3}$

According to Namik Kemal and his colleagues, public opinion in this garb that is in the form of substantive rationality, would be the basic means of resistance to the sultan's and his ministers' absolutism. It would also provide a set of guidelines for the subsequent governments. Public opinion was to be shaped by the intelligentsia; Namık Kemal and the other members of the intelligentsia regarded European civilization as an artifact created by skill and ingenuity rather than as a product of social forces. ${ }^{4}$

Consequently, the elite journalists of the time (as well as those of the later periods) took on the role of didactic intermediaries between an idealized West and 'a backward society'. ${ }^{5}$ This particular orientation was reflected even in the very name of most of the newspapers started from the 1860s onwards: Tercüman-1 Ahval (1860) (the Interpreter of Events), Tasvir-i Efkâr (the 
Depiction of Opinion) (1862), Muhbir (Informer) (1866), Tercüman-1 Hakikat (the Interpreter of Truth) (1878), and the like. When the outspoken journalists of the 1860s attracted the government's wrath and had to transfer their journalistic activities to various European capitals, the first London issue of Muhbir noted that it had 'found a country where it is not forbidden to tell the truth' ${ }^{6}$ Elite journalists were invited to Europe by a self-exile, Mustafa Fazll Pasha, who invited them to work for the happiness and the salvation of their country.' Earlier Şinasi, one of the leading disciples of Namık Kemal, had noted in an editorial he had written in the first issue of Tasvir-i Efkâr that one could serve one's country first and foremost by teaching people to think in terms of the general interest. ${ }^{8}$

Henceforth, elite journalists doubled up as the sole interlocutors of civil society, representing its collective interests, that is as an alternative state elite. ${ }^{9}$ In both Ottoman and Republican Turkey, journalists played an important role in introducing Western values and institutions to society. From 1923, when the Republic was proclaimed, until 1945 when a multi-party system was installed, journalists had been instrumental in propagating the modernizing reforms of the one-party regime. ${ }^{10}$

Following the installation of the multi-party regime, journalists, along with the other statist intellectual-bureaucratic elites, became the champions of rational democracy. For them politics meant enlightened debate informed by a well-defined world view - Atatürkist principles (of republicanism, nationalism, secularism, populism, étatism, and reformism) or different shades of left-wing or right-wing ideologies." Journalists judged different governments in terms of the world views they themselves subscribed to at the time and, depending upon that judgement, they either enthusiastically supported or fervently opposed them. Thus the bulk of the press was in a state of virtual warfare with the Demokrat Party governments of the $1950 \mathrm{~s}^{12}$ and the Motherland Party governments between 1983 and $1991 .{ }^{13}$ In both cases, the 'antisecularist' and market-oriented economic policies of these governments were heavily criticized and the politicians pursuing these policies were sharply denounced.

Journalists in Turkey competed with political elites in their claims to the true expression of popular aspirations; they themselves defined, in a true Jacobinist manner, what those aspirations should be. As 'representatives' of civil society, they challenged political governments when those governments did not hold the same views that they themselves espoused, or when these governments did not function in a manner journalists thought they should.

Until at least the 1960s, elite Turkish journalists favoured a representative government. Along with the other statist elites in the ranks of the bureaucracy, the military, and the Republican People's Party, they thought that they could influence governments through shaping public opinion in line with the views 
they themselves held. ${ }^{14}$ As already noted, they were the champions of rational democracy. When, in the subsequent years, other statist elites gradually lost their power and the political elites came to dominate the Turkish polity, ${ }^{15}$ journalists began to subscribe to the idea of participatory democracy. ${ }^{16}$ They considered the latter type of democracy basically as a more effective weapon against the political elites with which they disagreed on specific issues. In other words, they did not shed their rationalistic inclinations.

It is true that particularly in the post-1980 period, journalists increasingly began to place the daily life of society in the foreground of the news and to voice the particularistic aspirations and demands of some disparate civil societal groups. ${ }^{17}$ Consequently, their support of participatory democracy may be interpreted as a genuine wish on their part to see civil societal groups efficaciously participating in politics. However, this does not seem to be the case. The owners of newspapers were basically interested in increasing sales, as was evidenced by the policies of sensationalism and give-away and lottery campaigns. ${ }^{18}$ In his recent study of journalists, Şahin Alpay has described them as 'cautious democrats'. Alpay has detected even among journalists themselves some scepticism about the firmness of the commitment of the Turkish press to democratic principles and values, and a tendency towards regarding democracy as freedom of expression for themselves only and not for others. ${ }^{19}$ Earlier Orhan Koloğlu had reported that in the early 1970s some journalists had urged the military to take over the government. ${ }^{20}$ Given their Jacobinist past, these lingering elitist attitudes are not surprising.

Journalists have also been an influential group. The freedom of the press in Turkey goes as far back as the Imperial Rescript of the Rose Chamber issued in 1839 to ward off European encroachment on the Empire. Since then, from time to time some of the freedoms granted earlier were taken back, but, on the whole, over time the scope of the freedoms has consistently become wider. The most important phase in this development was the adoption of the 1961 Constitution which contained fairly liberal provisions concerning the freedom of the press. Consequently, despite the fact that at times they faced suppressive governments, the press managed to keep its head above water, particularly in recent decades. ${ }^{21}$ Not only did the press survive difficult times, but it left its imprint on political developments in Turkey.

Indeed, as early as 1865 some members of the press joined the first revolutionaries who, two years later, were organized abroad as the Young Ottoman Society. The organization called for a representative and constitutional government. Subsequently, the 1876 Constitution introduced a representative monarchy. ${ }^{22}$ It has been noted that in 1875-76 and 1908 the people took to the streets as a consequence of fiery press criticisms of government policies. ${ }^{23}$ Even during the single-party years of 1923-45, the press often obliged the government to reverse its decisions. On one occasion the government had to 
lift the restrictions it had placed on the press itself. ${ }^{24}$ The coming to power of the Demokrat Party in 1950 and the downfall of the Motherland Party government in 1991 have also been attributed, first and foremost, to the mobilization of the public opinion by the press. ${ }^{25}$ The press also played a crucial role in the relatively rapid re-democratization of the regime following the 1980 military intervention. ${ }^{26}$

After 1983 the Turkish press became a significant actor in politics. This was because, as already noted, the statist elites in the ranks of the bureaucracy, the military, and some political parties became less and less influential. This vacuum was not filled by civil societal groups. ${ }^{27}$ Instead, politicians and journalists have emerged as the two dominant groups. Some journalists had the ear of politicians. Leading columnists frequently reported what ministers, prime ministers, and even presidents had told them the day before on the phone or over breakfast. These journalists seemed to be boasting of having the ear of leading politicians while the latter were quite eager to stay in the limelight thanks to the attention of the press. ${ }^{28}$

One may thus conclude that journalists have become not just the third but the second estate in Turkish politics, after the politicians. As Turkish politicians of the early 1990s have tended to place as much emphasis on their public image as on concrete policies as a means to garner votes, one may even go as far as to suggest that journalists in Turkey have recently become the first estate. Under the circumstances, the following question has become critical in the Turkish context: having taken their place near the political helm, have Turkish journalists been contributing to political stability in general and to prudent government in particular, while they have been still acting as selfappointed spokespersons for civil societal elements? In other words, do they still maintain or have they shed their earlier attitude to politics? In other words, are they interested exclusively in passing definitive verdicts on regime issues in terms of the world-views they tenaciously hold, looking at issues in black and white?

We have examined from this perspective the attitudes towards some specific political events of three influential columnists writing in four leading newspapers in Turkey. Three of the four newspapers chosen (Sabah, Hürriyet and Milliyet) have the highest nation-wide circulation in Turkey, lately usually in that order. They are basically centrist newspapers. The fourth one (Cumhuriyet) has a relatively low circulation, yet it is widely read among the intelligentsia. Cumhuriyet is a moderately left-of-centre newspaper. ${ }^{29} \mathrm{We}$ have not chosen newspapers propagating views at the fringes of the political spectrum because, as Juan Linz has argued, the attitudes and values of only the pro-system actors are critical for the consolidation of democracy. ${ }^{30}$ The 
specific political events we have chosen as occasions to investigate the attitudes of leading columnists were the resignation of Chief of the General Staff Necip Torumtay on 3 December 1990, the election of Süleyman Demirel as President of the Republic on 16 May 1993, and the Prosperity Party's unexpected success in the 27 March 1994 local elections.

It was for the first time in the history of the Turkish Republic that a chief of the general staff resigned his post because he had some differences with the government instead of coming up with '. . . some sort of a warning or ultimatum as many of his predecessors might have done'.$^{31}$ Torumtay's resignation letter, which came in the middle of the Gulf Crisis, read: 'The principles I believe in and my understanding of the manner in which the state should function make it impossible for me to go on holding this office [of chief of the general staff].' At the time this was the only explanation he had offered concerning his resignation. President Turgut Özal reacted by saying, 'Resignation is a normal act in a democracy'.

Given the fact that since the installation of multi-party politics in Turkey in 1945 the military had intervened three times (1960-61, 1971-73, and 198083), Torumtay's decision to resign rather than send an ultimatum to the government had important implications for Turkish politics. It could be interpreted as clear-cut evidence of a further de-militarization of politics in Turkey or, conversely, it could be seen as a sign of serious misgivings on the part of the military towards civilian politicians and, thus, a harbinger of a possible re-militarization of the Turkish polity. Under the circumstances the prudent thing to do was to downplay the whole incident and report it as an ordinary resignation of a state official and/or to discuss and evaluate the possible policy differences between Torumtay and Özal in a rather detached manner.

Instead, only one columnist preached restraint and, among other things, suggested that the resignation should not be seen as an outcome of a civilian-military conflict but rather as a consequence of a mere conflict of opinion that may arise between any subordinate and his political master (E. Özkök, Hürriyet, 4 December 1990). Even this columnist, however, arrived at the conclusion that in the face of this particular development, Özal should abandon his active policy in the Gulf Crisis. G. Civaoğlu of Sabah also took the resignation as a 'possible brake' on Turkey's making a foreign policy commitment that might cost Turkey very dearly (5 December 1990). Along the same lines, an editorial in Cumhuriyet saw Torumtay's leaving his post as an effort, on the part of the military and on behalf of the Turkish Republic, to prevent Turkey from engaging in an armed conflict (4 December 1990). Both Özkök and Civaoğlu and the editorial in Cumhuriyet took it for granted that because the chief of the general staff disagreed with it, Özal should abandon his policy. By taking this particular stand, journalists could be accused of lending implicit support to the view that the military had the 
last word on such matters, if they chose to pronounce it. However, as one could not on the whole doubt their democratic credentials, the journalists' stand on this issue could be explained only in terms of their immense dislike of Özal.

Some other columnists who had similar attitudes, held Özal responsible for Torumtay's resignation. Some of them bitterly criticized the manner in which Özal had acted as president. M. Soysal of Milliyet argued that Torumtay's resignation was a consequence of Özal's efforts to create an 'alla turca presidential system' (6 December 1990). O. Ekşi of Hürriyet attributed the resignation to Özal's giving short shrift not only to the government and the office of chief of the general staff but also to the parliament (6 December 1990). And G. Civaoğlu of Sabah argued that under Özal, democracy in Turkey had been going through a process of degeneration (9 December 1990). Others in this latter group did not mince their words and claimed that Özal's regime had been drifting towards a 'civilian dictatorship'. D. Sazak of Milliyet observed: 'After so many years [following Celal Bayar's presidency in the 1950-60 period], again we have a "civilian" president elected to that post without the military's support behind him. Yet that very Özal, who has always boasted that the presidential office is no longer an officers' mess, is now conducting his presidency as a civilian dictator' (5 December 1990). The most bitter attack on Özal came from I. Selçuk of Cumhuriyet: 'In our times there are so many simpletons; when one comes across someone who is not, like Torumtay, one becomes pleasantly surprised.... Is it not high time that someone gave a warning to the president who is irresponsibly moving Turkey to war ... and to an authoritarian regime?' (6 December 1990).

Still more critically, some columnists presented the whole affair as a serious conflict between the military and the civilian government. Milliyet reported the resignation under big headlines which read, 'A Resignation like an Ultimatum [to the Government]'. Both M. Soysal of Milliyet (6 December 1990) and O. Ekşi of Hürriyet (5 December 1990) wrote that the political implication of the resignation was quite significant and that the Turkish polity faced a critical situation. Others who also magnified the whole issue into a virtual crisis situation, were keen to apportion blame. A. Öymen of Milliyet was one of those columnists who exonerated Torumtay:

When a civilian and an officer cannot agree on a matter we do not try to find out who is right and who is wrong; we instinctively take the side of the civilian so that nobody can doubt our democratic credentials ... One cannot decide whether someone is a democrat or not on the basis of his/her being a civilian or an officer. One may come across democrats among the officers, too. Torumtay is one such officer . . . Among civilians, too, you may find people who are not democrats at all. For 
instance, can one think of those in the parliament who have turned over all authority to Özal, as democrats? (6 December 1990)

In contrast, G. Mengi of Sabah blamed the military: 'We do not think that a political stand as in the Torumtay affair befits the military. We earnestly expect the civilian government and the military to dispel doubts and let the people have confidence about the future of the democratic regime in Turkey' (5 December 1990).

Finally, some columnists, in addition to underlining the 'critical' nature of Torumtay's resignation, implied that this resignation was perhaps the first step towards a much more serious showdown between the military and the government. C. Arcayürek of Cumhuriyet implied exactly this when he asked: 'What does this resignation really signal?' O. Ekşi of Hürriyet wrote: 'We should decide where we all stand; we may soon face some new developments' (5 December 1990). The most explicit statement on the possible development many journalists had in mind came from E. Özkök of Milliyet: 'Let us not forget: ten years ago, too, the military had the people's moral support behind them when they acted against . . . the political parties in the parliament' (5 December 1990).

On 17 April 1993 President Turgut Özal died. Soon afterwards Prime Minister Süleyman Demirel announced his candidature for the presidency. Demirel had been twice removed from the premiership by military interventions (1971 and 1980). Partly as a consequence of having been removed from power by force and partly because he had inherited the mantle of the Demokrat Party of the 1950s, Demirel had always been an urgent proponent of democracy based on the 'national will', that is a democracy that serves the best interests of the people and not of the state. During Özal's premiership from 1983 to 1989, Demirel had fiercely criticized Özal for having always had the implicit support of the military. Demirel argued that Özal had been elected to the presidency by a political party which according to the opinion polls did not represent at the time a large cross-section of the electorate and, therefore, lacked 'legitimacy' as president, and that he had discharged the presidential office in a 'partisan' manner. ${ }^{32}$ Demirel had promised to topple Özal from power when he himself came to power. Demirel was elected president on 16 May 1993.

The (1982) Constitution had created a strong presidency in an otherwise parliamentary system of government. If the president had been a member of a political party he/she was to resign from his/her party; the presidency had to be conducted in a non-partisan manner. The president had the power to make key appointments. The president was to represent the Republic of Turkey and the unity of the Turkish nation and to ensure the implementation of the Constitution, as well as the regular and harmonious functioning of the organs of the State (Article 104 of the Constitution). 
When Demirel became a candidate for the presidency, one would have expected the press to take up the issue of whether Demirel had the necessary qualifications for that office. Only one columnist (E. Özkök), however, addressed this question: '[Today in Turkey a president should be someone who is] an influential person on the international scene, respected in society, able to set the political agenda when he deems it necessary, politically experienced so that he has at least a moral authority over the parliament, and someone who, in times of crisis, can use his charisma to overcome difficulties' (Hürriyet, 28 April 1993). Yet even Özkök did not pay attention to the fact that the 1982 Constitution had created a strong presidency; Özkök added: 'At this time, in a country like Turkey one cannot have a president who, in his conduct of his office, goes beyond the function of a symbolic representation [of the state].'

Others altogether overlooked the issue of the qualifications Demirel should have. Some among the latter emphasized only non-partisanship; these columnists had in mind 'the partisan Özal'. D. Sazak observed: 'As long as the new president acts in a neutral manner towards the political parties and the political leaders he will keep himself out of the political disputes and will not be another Özal' (Milliyet, 18 May 1993). C. Arcayürek, too, pointed out that what Turkey needed first and foremost was to have a president who would stay within the framework of the Constitution and maintain his neutrality' (Cumhuriyet, 19 April 1993).

Only one columnist, T. Akyol, was optimistic on this score. He compared Demirel and Özal, and arrived at the conclusion that because of his particular temperament, Demirel would remain non-partisan (Milliyet, 21 April 1993). But many others made pessimistic predictions about Demirel's behaviour as president on the basis of his past political record. M. Soysal of Hürriyet, for instance, found Demirel not fit for president because Demirel had become too closely identified first with the Justice Party and later with that party's successor, the True Path Party (24 April 1993). Similarly an editorial in Cumhuriyet has argued that whenever Turkey had a partisan president we came to have serious problems in public life (19 April 1993).

In line with this particular approach some columnists urged Demirel to seek a wide consensus for his presidency. These columnists had in mind the controversies that had arisen about the legitimacy of the Özal presidency, because Özal was elected president in 1983 on the strength of only the Motherland Party (MP) votes in the parliament. At the time, opinion polls were showing that the MP had far less support among the electorate than its seats in the parliament implied; as already noted, this had been taken by many as evidence that Özal represented only a relatively small percentage of the electorate and, therefore, his presidency could not be considered 'legitimate'. A. Öymen of Milliyet and M. Soysal of Hürriyet criticized Demirel because he had 
announced his presidential candidature without having first consulted other party leaders (both on 25 April 1993). Similarly I. Selçuk of Cumhuriyet suggested that although Demirel did not need to obtain the support of all political parties he should nevertheless represent the majority of the electorate (1 May 1993).

Still another argument which informed some columnists' approach to the issue and which again had nothing to do with the qualifications a president needed in Turkey at the time, was that Demirel's presidency would be victory for democracy in Turkey. Z. Livaneli of Sabah wrote: 'As long as a civilian is elected president, the victor will be the democracy. One or two persons have suggested some officers as possible candidates, but nobody takes them seriously ... . What is important is that we institutionalize the election of civilians to the presidency' (25 April 1993). Similarly G. Civaoğlu of Sabah commented: 'In fact, democracy itself was elected to Çankaya [where the presidential palace is situated] . . because for a long time Demirel shouldered single-handedly the struggle for democracy' (18 May 1993).

Another argument, related to the last point, was that Demirel deserved the presidency because of his past record in general. According to E. Özkök of Hürriyet, the presidency was not only the top public office but also a place to which one would bring persons in order to honour them for a long and difficult political career (20 April 1990). O. Ekşi of the same newspaper agreed with Özkök while looking at the issue from a different perspective: 'When he is elected the leader of his party, that is when he shows that he has the capacity and skill for that post nobody disapproves it, but when he wants to use that capacity and skill in a higher public office, objections are raised. This does not make sense' (9 May 1993). G. Mengi of Sabah also made a similar assessment: 'Not unlike other politicians, Demirel, too, has his supporters and detractors. But nobody can claim that he does not deserve that post. Throughout his political career Demirel believed in the people and had been an ardent proponent of the rule of law' (16 May 1993).

Mengi had been one of Demirel's detractors. Thus he came up with another reason why Demirel should be elected president (read, 'kicked upstairs'): 'Demirel's climb to Çankaya does not mean depriving the True Path Party of a leader; it means that the party will now have an opportunity to prove its worth. Not only the True Path Party but also Turkey [will have that opportunity] ... . We could not earlier remove Demirel from top political positions by any other means; we can now get rid of him by elevating him to the presidency' (11 May 1993). G. Civaoğlu of Sabah (11 May 1993) and E. Özkök of Hürriyet (20 April 1993), too, considered Demirel's presidency as an opportunity to have new blood in Turkish politics.

At the 27 March 1994 local elections, the religiously oriented Prosperity Party (PP) in alliance with two marginal parties obtained the highest vote (18.3 
per cent) that any religiously oriented party in Turkey had ever garnered before. This result came us a shock to many people in a country that had been trying to Westernize during the last two hundred years. There were fears among some that following the next general elections (to be held at the latest in 1996), the PP would become an indispensable partner in any coalition government and could even form a majority government. Others were less worried. They figured that many votes that went to the PP were protest votes; if the other parties put their house in order they could regain the votes they had lost. One could also stop the PP, the latter thought, if one adopted run-off elections. In any case, if one respected the fundamental principles of democracy one would have been hard put to preach drastic action against the PP as long as the party did not challenge those principles. It was, therefore, necessary to urge restraint on both the religiously oriented and the secularists - to ask the PP not to try to turn the clock back in Turkey and to urge the secularists to learn to live with the religiously oriented.

As in the first two cases discussed here, journalists were sharply divided. One group was rather concerned about the PP's success; their concern was often mixed with anger, which was directed at the secularists, too, for their 'thoughtlessness had contributed to the PP's success'. M. Soysal of Hürriyet, for instance, criticized the secularist women who took reformism to mean praising Atatürk and doing nothing else, and has argued that their loud predictions that if the PP came to power women would have to cover their heads and wear long skirts, had made the religiously oriented angrier and bolder ( 3 April 1994). Other columnists directed their wrath at 'naïve secularists' who had belittled the potential danger, at non-religious parties who had let the PP reach its present standing in the Turkish polity by their ineptness, and at the PP itself for the its ominous designs for Turkey. O. Ekşi of Hürriyet wrote: 'Since 1991, the PP's vote has increased by 80 per cent. Those who always claimed that the secularists who had been concerned about a religious revival in Turkey were day-dreaming, should now themselves consult an eye doctor' ( 28 March 1994). An editorial in Cumhuriyet has pointed out that 'overlooking the obvious danger [of a religious revival in Turkey] . . . is no different from committing a crime against the future generations in this country' (14 April 1994). Politicians in the basically secularist parties were singled out as the main culprits. Ilhan Selçuk of Cumhuriyet quipped: 'The long-term investment in Sharia [the Muslim Code] has finally borne fruit' (30 March 1994). The editorial in the same issue of Cumhuriyet suggested that the PP's victory was a consequence of the constant squabbling among the incompetent politicians in Turkey. O. Ekşi of Hürriyet accused the past and the present governments of having contributed to the revival of Islam in Turkey by, among other things, opening many new (High) Schools of Prayer Leaders and Preachers and not taking measures against the continuing degeneration of political morality 
coupled with social injustice (30 March 1994). D. Sazak of Milliyet warned that unless Prime Minister Tansu Çiller could do something about the worsening economic situation, in the next general elections the PP would come out on top (30 March 1994). Sazak also had hard words on the leading members of the PP: 'Leaders of the Prosperity Party view their mission far beyond administering municipalities; from the very first day, they have attempted to impose on people a regressive life style. And, in order to conceal their real intentions, they have been making statements like, 'Do not worry, Turkey would never become an Algeria'. Sazak then tried to console his readers: 'Anyway, nobody in Turkey at the turn of the century would believe in this idle-talk' (31 March 1994). However, worried opponents of the Prosperity Party were not quite sure about the ability of the secularists to stop the PP through democratic means; consequently they hid an iron hand in a velvet glove. An editorial in Cumhuriyet commented: 'Being against the PP is increasingly meaning being against the Sharia [read, the Islamic way of life]; people are beginning to take a definitive stand against the PP' (22 March 1994).

Nevertheless the columnists called for democratic means to prevent the PP from capturing government. A worried opponent of the PP, O. Ekşi, wrote in Hürriyet that, 'Presently Turkey's most important problem is to prevent the PP from coming to power through democratic means' (5 April 1994). G. Mengi of Sabah suggested that 'only in an open regime would the people begin to realize the PP's real intentions' (15 April 1994).

However, others tried to avoid both exaggeration and complacency in the face of the PP's recent success at the polls. A. Öymen of Milliyet wrote: 'We should not forget that no matter how great the increase in the PP vote, it still hovers around 18 per cent. And the PP's victory in almost all constituencies is due to the fact that the elections were not run-off elections' (30 March 1994). G. Mengi of Sabah, too, has arrived at an optimistic conclusion: 'With 18 per cent of the vote, the PP cannot form a government. That means it will have to placate other voters, too . . . . The party will either adopt a model based on human rights or else will become an even smaller party by losing the protest votes it managed to obtain in these elections' (30 March 1994). E. Özkök of Hürriyet made a more general evaluation and came up with an assessment like those of Öymen and Mengi: 'Turkey is neither Iran nor even Algeria. In Turkey more than 80 per cent of the electorate had been thoroughly Westernized; they would no longer adopt a different life style. Turkish capitalism is also too advanced to be fitted to the PP's [religiously informed economic model of] Just Order' (2 April 1994). D. Sazak of Milliyet (31 March 1994) and M. Soysal of Hürriyet (31 March 1994) have not disagreed with Öymen, Mengi and Özkök, but they have argued that the secularly oriented parties should at once attend to the ills of the polity and society, which 'are behind the PP's success'. 
Those columnists who were less concerned emphasized the need for mutual tolerance and respect between the secularly and the religiously oriented, and urged restraint on everybody. A. Öymen of Milliyet asked the 'victors' not to be too proud and aggressive and the 'losers' not to feel too disappointed and bitter (30 March 1994). T. Akyol of Milliyet underlined the danger of splitting into two hostile camps (31 March 1994). Referring to some such isolated rowdy acts on the part of a few members of the PP as asking women to dress more modestly in the morning after the local elections, G. Civaoğlu of Sabah urged the government not to react to the culprits too harshly and alienate the bulk of the law-abiding supporters of the PP. But he also reminded the PP of the need to respect the law (3 April 1994).

The major theme of the less concerned was that we live in a democracy and that, therefore, we need to learn to live harmoniously together. T. Akyol of Milliyet wrote that if we believe in democracy we have to recognize the legitimacy of the role the PP plays in Turkish politics (31 March 1994). G. Mengi of Sabah observed: 'These people have not come from Iran, Iraq or Libya. Neither they nor those who disagree with them will leave this country. We shall all continue to live in this country' (2 April 1994). A. Öymen of Milliyet elaborated: 'We should respect each other despite the differences in our views and life-styles. We should not try to impose by force our views and life-styles on others' (1 April 1994).

In Turkey, journalists aspiring to bring about political reform emerged in the 1860s. During the second part of the nineteenth century, when rulers tried to cut them down to size, they transferred their publishing activities to European capitals and continued to try to shape the course of events in Turkey from abroad. When the Second Constitutional Period started in 1908, journalists gained additional self-confidence and the scope of the freedom of press was considerably widened. During the single-party years of the Republican period (1923-45), many journalists joined the ranks of the Republican People's Party and helped propagate the new Republican values. Others tried to oppose the governing party and advocated the liberalization of the regime. Journalists put up a fight against the oppressive press regime of the 1950s. With the 1961 Constitution press freedom in Turkey approached that in the West, except during the military interregnums and more recently because of the struggle with Kurds in southeastern Turkey.

Having emerged as a counter-elite, journalists in Turkey have been far from neutral brokers. They have, in fact, aspired to a role more dominant than that of active and participant journalists in the continental European style, for they wish not only to influence but to shape political regimes, policies, and the course of events in the polity and society. ${ }^{33}$ They have perceived themselves as 
the guardians of the public interest, as they themselves interpreted it. Despite their rhetoric of democracy, even in its participatory version, they have considered themselves as the holders of ultimate truths. These Jacobinist journalists who have subscribed to rationalist democracy have tried to shape the political regimes' policies, and the course of events in polity and society by trying to mould public opinion. They looked on democracy as basically their freedom to engage in this type of activity and they regarded as undemocratic those who either introduced or failed to lift restrictions on journalists or those who did not heed their pontifications. Thus most journalists became hostile to the military, who restricted their activities from time to time, to Özal, who for the most part cold-shouldered them, and to Demirel, who had always been engaged in patron-client relations and had not therefore been responsive to the journalists' idealistic policy schemes, and who in recent years had reneged on his promise to further democratize the regime.

These biases on their part sometimes distorted journalists' perceptions of some critical issues. When that happened they tended to magnify the issues, sometimes to crisis proportions, which, of course, did not bode well for regime stability and for maintaining a delicate balance between political participation and prudent government, both of which are critical for the consolidation of democracy.

The journalists' defence of Torumtay against Özal could not be reconciled with their rhetoric of democracy; their enmity to Özal overrided all other considerations. At the same time, they tended to view Torumtay's resignation as more evidence of 'the ongoing military-civilian clash'; their approach to this issue derived from their well-entrenched hostility towards the military. Similarly, the journalists' failure to pay attention to the qualifications a president needed to have in Turkey in the early 1990s was due to their love-hate relationship with Demirel: they liked him because he had been a warrior for 'democracy' - as a consequence, they argued that Demirel deserved the presidency, but they hated him because he had not always acted as they would have liked him to act - consequently, they were glad to see him kicked upstairs. The journalists' tendency to magnify some problems to crisis proportions and to set false agendas endangered political participation and made prudent government difficult.

When the issue had been one on which journalists and mainstream politicians did not differ fundamentally, there was, of course, less criticism. On such occasions the journalists were on the whole attentive to the real issues and they displayed a higher degree of common sense. Consequently, instead of inflating the PP's recent victory at the polls into a crisis situation, many journalists urged restraint on everybody and tried to contribute to the development of a harmonious relationship between the secularists and the religiously oriented. 
In Turkey, because journalists have not tended to consider themselves as neutral brokers, as in the Anglo-American contexts, and have not been content merely to influence politics, as in continental Europe, they have sometimes introduced unnecessary tensions into politics that have endangered political participation and interfered with prudent government. On the other hand, unlike the situation in many Third World countries, journalists in Turkey have not acted as spokespersons for demands, which are very difficult, if not impossible, to meet. ${ }^{34}$ Turkish journalists have not been captive of religious, ethnic and other difficult-to-resolve claims, and have therefore been open to learning. There was evidence of this learning process in the press treatment of the recent success of the religiously oriented PP at the polls. The greater sophistications displayed over this issue promises to remove one more obstacle to the consolidation of democracy in Turkey.

\section{NOTES}

Martin Heper gratefully acknowledges the financial support he received from the Turkish Academy of Sciences for the research leading to this article.

1. Bernard Lewis, The Emergence of Modern Turkey (London: Oxford University Press, 1961), p.146.

2. Cited in Kemal H. Karpat, 'Turkey [: the Mass Media]', in Robert E. Ward and Dankwart A. Rustow (eds.), Political Modernization in Japan and Turkey (Princeton: Princeton University Press, 1964), p.261.

3. Lewis, The Emergence of Modern Turkey, p.158.

4. Karpat, 'Turkey [: the Mass Media]', p.261.

5. Şahin Alpay, 'Journalists: Cautious Democrats', in Metin Heper, Ayşe Öncü and Heinz Kramer (eds.), Turkey and the West: Changing Political and Cultural Identities, (London and New York: I.B. Tauris, 1993), p.88. Also see Gérard Groc, 'Journalists as Champions of Participatory Democracy', in Metin Heper and Ahmet Evin (eds.), Politics in the Third Turkish Republic, (Boulder, San Francisco, and Oxford: Westview Press, 1994), p.200.

6. Lewis, The Emergence of Modern Turkey, p.150. Our emphasis.

7. Ali Gevgilili, 'Türkiye Basını', Cumhuriyet Dönemi Türkiye Ansiklopedisi, fascicle 7, p.205.

8. Ibid., p.204.

9. Ahmet Oktay, Toplumsal Değişme ve Basın (Istanbul: BFS, 1987), p.45.

10. Alpay, 'Journalists: Cautious Democrats', p.88.

11. Metin Heper, The State Tradition in Turkey (Walkington, UK: The Eothen Press, 1985), Ch.4.

12. See Feroz Ahmad, The Turkish Experiment in Democracy, 1950-1975 (London: Hurst, 1977), pp.88ff, 93.

13. Groc, 'Journalists as Champions of Participatory Democracy', p.205.

14. The Republican People's Party had been the single party in the 1923-45 period; it was the carrier of the Atatürkist principles and the champion of rationalist democracy. We take rationalist democracy here as does Sartori where one comes across deference to general abstract principles which are taken as self-evident truths. Sartori, The Theory of Democracy Revisited (London: Chatham House, 1987), p.52.

15. For this particular evolution in Turkish politics, see Metin Heper, 'The State, Political Party, and Society in post-1983 Turkey', Government and Opposition, 25 (1990), pp.321-53.

16. Groc, 'Journalists as Champions of Participatory Democracy'. 
17. Ibid., pp.201, 207.

18. These policies have been developed as a reaction to the Motherland Party governments' policies to control the press through economic means. For an elaboration, see Groc, 'Journalists as Champions of Participatory Democracy'.

19. Alpay, 'Journalists: Cautious Democrats', pp.78, 79.

20. Orhan Koloğlu, Osmanlı'dan Günümüze Türkiye'de Basin (Istanbul: lletişim, 1992), p.114.

21. Ibid., pp.88-9.

22. Karpat, 'Turkey [: the Mass Media]', p.20.

23. Ibid., pp.263, 269.

24. Ibid., p.278.

25. Ibid., pp.278-9; Groc, 'Journalists as Champions of Participatory Democracy', p.209.

26. Alpay, 'Journalists: Cautious Democrats', p.89.

27. For an elaboration, see Metin Heper, 'Trials and Tribulations of Democracy in the Third Turkish Republic', in Heper and Evin (eds.), Politics in the Third Turkish Republic, pp.23141.

28. See Metin Toker, 'Siyasetçi-Medya Ilişkisinin Anatomisi', Milliyet (Istanbul daily), 7 October 1994.

29. The columnists chosen were Oktay Ekşi, Ertuğrul Özkök, and Mümtaz Soysal of Hürriyet, Güneri Cıvaoğlu, Zülfü Livaneli, and Güngör Mengi of Sabah, Taha Akyol, Altan Öymen and Derya Sazak of Milliyet, Cüneyt Arcayürek, Ilhan Selçuk and the anonymous writer of the editorial column of Cumhuriyet. In Hürriyet, Sabah, and Milliyet, Oktay Ekşi, Güngör Mengi, and Altan Öymen, respectively, wrote at the time the editorial column.

30. Juan Linz, The Breakdown of Democratic Regimes: Crisis, Breakdown, and Re-equilibration (Baltimore and London: Johns Hopkins University Press, 1978), p.50.

31. William Hale, Turkish Politics and the Military (London: Routledge, 1994), p.292.

32. See Metin Heper, 'Consolidating Turkish Democracy', Journal of Democracy, 3 (1992), pp.105-17.

33. James W. Carey has referred to the Anglo-American press tradition as 'communication school' and to the continental European tradition as 'ritual school'. See his Communication as Culture: Essays on Media and Democracy (Boston: Unwin and Hyman, 1988), p.14.

34. On the situation in many Third World countries, see Samuel P. Huntington, The Third Wave: Democratization in the Late Twentieth Century (Norman and London: University of Oklahoma Press, 1991), pp.7, 10, 101-2 and Vicky Randall, 'The Media and Democratisation in the Third World', Third World Quarterly, 14 (1993), pp.625-46. 